УДК 377.8.016:821

DOI: $10.37026 / 2520-6427-2020-101-1-63-66$
Наталя РОМАНИШИНА,

докторка педагогічних наук, дочентка, завідувачка кафедри украӥнської літератури

Рівненського державного гуманітарного університету
Лідія ГРЕСИК,

студентка магістратури

Рівненського державного гуманітарного університету

\title{
МЕТОДИКА АНАЛІЗУ ХУДОЖНІХ ТВОРІВ У ЗІСТАВЛЕННІ 3 КІНЕМАТОГРАФІЧНИМИ АДАПТАЦІЯМИ
}

У статті представлено розробку та апробацію методики кіноосвіти у вишій школі, визначення ї̈ педагогічних форм, засобів, змісту, а також особливостей організації діяльності викладача та студента. Окреслено кониепиії порівняльного культурологічного аналізу художніх творів та кінотворів.

Ключові слова: методика навчання літератури у вищій школі, методика культурологічного аналізу, медіаосвіта, кіноосвіта, екранізація.

В статье предложена методика кинообразования в высшей школе, определение ее педагогических форм, средств, содержания, а также особенностей организации "кинодеятельности» преподавателя $u$ студента. Очерчена кониепция сопоставительного культурологического анализа художественных произведений и экранизаций.

Ключевые слова: методика преподавания литературы в высшей школе, методика культурологического анализа, медиаобразование, кинообразование, экранизащия.

Methods of film education in higher education, in particular determination of its pedagogical forms, means, content, features of organization of activity of teacher and student; the concept of analysis of films and works of art, due to the fact that many works of classics of Ukrainian literature are "translated» into the language of the screen, adaptation has become a trend that is ready to pick up Ukrainian film producers, while in society there is a steady fall in demand for books by classical writers, prevail transmission, including educational information, is defined by the contemporary cultural space as "screencentric».

The purpose of activities in classics using film presentations is a comparative analysis of a literary work and its adaptation in order to study the features of intersemiotic transcoding, to identify new meanings of the first text, the formation of value orientations, cinematic culture, emotional development of students.

Defining the content of the study and choosing the film adaptation, the teacher takes into account the closeness to the primary source, whether the film is an imitation of literary classics, or meets the definition of "high art». Cultural methodological analysis on the methodological basis of literary studies includes the interpretation of classical works taking into account the expressive means of literature and cinema, depicted images of the era, cultural realities, multifaceted interpretations of literary text in various types of art (illustrations, theatrical, musical, film adaptations).

Thinking of the adaptations in the methodological perspective is connected with modeling of the mediaeducational process in high school, informatization of education, application of the integrated approach to teaching of literature as realization of crosscurricular relations (pedagogy, literary criticism, film studies), audiolearning and video objects, forming students' imaginative, critical, audiovisual thinking.

Key words: methods of teaching literature in high school, methods of cultural analysis, media education, film education, film adaptation.

Постановка проблеми. У добу глобалізаційних процесів найпопулярнішим видом мистецтва $\epsilon$ кінематограф. Окрім того, кіномистецтво впевнено випереджає художню літературу, особливо серед молодіжної аудиторії. Оскільки значну кількість художніх творів класиків української літератури «перекладено» мовою екрану, викладачі літературознавчих дисциплін використовують на заняттях кінопостановки програмових текстів із метою заохочення студентів до прочитання першоджерел, інтеграції знань із різних видів мистецтва, підвищення ефективності процесу викладання літератури, формування культури, національної ідентичності молодих людей.

Актуальність теми зумовлена неоднозначними оцінками фактів звернення кінематографа до літературних творів, аж до неприйняття, заперечення («екранізації псують класичні літературні твори і тому їх краще не чіпати» [1]), відставанням України від розвинених країн світу, в яких шедевральні твори та бестселери екранізовано майже в повних обсягах; новими перспективами вироблення кіноверсій (зараз «екранізація - це тренд, який готові підхоплювати українські виробники кіно» [2]), потребою дослідження особливостей взаємодіїлітературийкіноуформікінематографічнихадаптацій у час невпинного падіння запиту на класику в контексті сучасного «екраноцентричного» культурного простору, переваги мультимедійного способу передачі інформації у світі; у зв'язку з ухваленням Концепції впровадження медіаосвіти в Україні. 
Аналіз наукових досліджень і публікацій. Екранізації літературних творів українських письменників $є$ предметом обговорення значної кількості вітчизняних мистецтвознавців, кінознавців, істориків кіно, літературознавців, мовознавців та методистів. У працях Л. Бербенець, Л. Брюховецької, Л. Госейка, В. Горпенка, С. Дарди, В. Кандинської, О. Лапко, А. Мазурак, А. Пащенко, В. Просалової, А. Ткаченка, Д. Шамардіної, К. Ямборської та ін. досліджується історія українського кінематографа, режисерські засоби і способи формування структури екранного видовища, специфіка функціонування різних видів мистецтва в умовах сучасного культурного простору, екранізація як форма безпосередньої взаємодії кіно та літератури; аналізуються, оцінюються окремі кіноверсії «прочитання» літературного твору, відомі кінематографічні інтерпретації класиків української літератури. Спогади, інтерв'ю з акторами, режисерами (С. Параджановим, I. Миколайчуком, Л. Осикою, О. Саніним, Ю. Іллєнком, М. Іллєнком та ін.), які згадують про роботу над втіленням у кіно художнього змісту літературного першоджерела, оприявнюють кон'юнктурні замовчування, ідеологічні та політичні спотворення тощо, допоможуть студентам відкрити для себе драматичний в українському кіномистецтві період, збагнути творчі тенденції, жанрову, тематичну новизну екранізацій XX століття. У працях методистів (Т. Бабійчук, С. Жили, Л. Неживої, О. Ратушняка, С. Скуратівської та ін.) здійснюються міжмистецькі порівняння літературного твору з українським поетичним кіно, діалоги із кіномистецтвом у контексті вивчення монографічної теми, інтегрованих уроків, позакласних заходів; розглядаються шляхи формування загальномистецької ерудиції, естетичного чуття учнів. Недостатньо розробленою та апробованою в Україні є методика кіноосвіти у 3ВО, визначення іiї педагогічних форм, засобів, змісту, особливостей організації діяльності викладача і студента; концепція аналізу кінотворів і художніх творів.

Мета статті - розглянути екранізації української літературної класики в методичній перспективі в контексті моделювання освітнього та медіаосвітнього процесу у вищій школі.

Виклад основного матеріалу. Українська класична література стала джерелом таких кіношедеврів, як «Наймичка», «Наталка-Полтавка» за п’єсами I. Тобілевича, I. Котляревського режисера Д. Сахненка; «Микола Джеря», «Дорогою ціною» за повістями I. Нечуя-Левицького, М. Коцюбинського - М. Терещенка; «Тарас Трясило» за поемою В. Сосюри П. Чардиніна; «Земля» та інші фільми за сценаріями О. Довженка; «За двома зайцями» за М. Старицьким В. Іванова; «Тіні забутих предків» за М. Коцюбинським - С. Параджанова; «Камінний хрест» та «Захар Беркут» за творами В. Стефаника, І. Франка - Л. Осики; «Втрачена грамота» за творами М. Гоголя Б. Івченка; «Вавилон XX» за романом «Лебедина зграя» В. Земляка - I. Миколайчука та ін. До успіху вітчизняного кіно українські письменники (О. Гончар, М. Стельмах, Ю. Дольд-Михайлик, П. Загребельний, В. Земляк, В. Шевчук та ін.) долучилися у 60 -х роках XX століття, пропонуючи фахові сценарії та повертаючи кіно до українських тем, національної культури, мистецтва, мови. До речі, на етапі екранізації твору сценарій є вторинною знаковою системою в низці «xyдожній твір - сиенарій - фільм», але часто не враховується в організації «кінодіяльності» у школі та 3ВО.
Фільми, зокрема української «поетичної школи», для яких характерні, як і для фольклору та літератури, метафорична, метонімічна, асоціативна образна система, філософські роздуми про людину, націю, історію, духовність, розповідь не про тогочасну дійсність, а про «естетичну сучасність» (I. Дзюба), універсальний досвід людства, названі кінокритиками «мистецтвом мислячого зображення» (Я. Газда), можуть осмислюватися в контексті здобутків кіно інших національних художніх напрямів (польська школа, фільми англійських розгніваних, французька нова хвиля, нове німецьке кіно, чеське диво тощо) на заняттях із літератури, що сприятиме збагаченню суб' єктивного досвіду студента-читача і глядача, розвитку інтелектуальних навичок, творчих, аналітичних здібностей.

Важливе питання, що постає перед педагогом та студентами, - наскільки можна наблизити екранізацію до твору? Окремі фанати вимагають від режисера буквального перенесення на екран оригіналу улюблених творів, включно з діалогами героїв. Критики й оглядачі щоразу зауважують невідповідність фільму першоджерелу. Наприклад, I. Дзюба у статті «День пошуку» згадує, що авторам фільму «Тіні забутих предків» дорікали у формалізмі, абстракціонізмі, що знято «не зовсім за Коцюбинським». Існує думка, що український читач зазвичай не готовий адекватно сприймати результат екранізації книжок, «бурчання на кшталт «зіпсували книжку» - такий самий неодмінний супровід перегляду, як дощ восени, комарі влітку чи зимові морози» [2]. Як відомо, українське кіно еволюціонувало від фільмів - «живих фотографій», «живих картин», «ілюстрацій» до художньо самостійних, «авторських» кінотворів. Екранізація як художня інтерпретація літературного твору - наслідок суб'єктивної рецепції тексту режисером, сценаристом, оператором, акторами, костюмерами, стилістами тощо зазвичай передбачає трансформацію художнього змісту першоджерела. Методист Л. Нежива, порівнюючи твори В. Стефаника і відзнятий режисером Л. Осикою кінофільм «Камінний хрест», наголошує на такій його перевазі: «не став калькованою екранізацією тексту новели» [4, с. 7].

Звичайно, кінофільм не може передати всі нюанси, значення, підтексти художнього твору, обмежує їх або, навпаки, переходить межі, надінтерпретує літературний текст. Наприклад, О. Муратов, режисер низки кінопостановок за прозою М. Хвильового, говорить про «вільне» поводження з матеріалом, визначає екранізацію як «не обов'язково точне відтворення книги на плівці»; в інтерв'ю «Я відновив спалені «Вальдшнепи» Хвильового» стверджує, що відтворив втрачену частину роману. Літературознавець В. Просалова рекомендує тлумачити цю екранізацію як «сиквел» - творче продовження художнього твору засобами кіно, але в межах визначеного попередником часу. У новій «голлівудській» версії екранізації повісті I. Франка «Захар Беркут» (2019 р.) режисери А. Сеїтаблаєв та Д. Вінн не лише доповнили сюжетні лінії, ввели нових персонажів, а й змінили ідейну концепцію; фільм із драми перетворився на мелодраму, сімейну історію, втратив важливі складові оригінального письменницького задуму.

«Продуктом масової культури» кінокритики назвали фільм за драмою «Украдене щастя» I. Франка (2004 р., режисер А. Дончик): осучаснення увійшло в суперечність із першоджерелом, драму шекспірівської напруги переведено у площину побутової історії з кримінальним сюжетом. 
Сучасні режисери часто наголошують на «відштовхуванні» від літератури, що фільм знято «за мотивами» художнього твору, акцентуючи на самостійності, авторській інтерпретації, способах екранного втілення. Наприклад, фільм «Дике поле» (2018 р.) уважається екранізацією роману С. Жадана «Ворошиловград», але при цьому режисер Я. Лодигін та письменник «домовилися» між собою про те, що книгу та фільм слід розмежувати і «залишити книгу позаду». Навіть назвою «ДепешМод» (2013 р.), без пропуску між словами, режисер М. Лук'яненко наголошує: фільм не буквальна екранізація роману С. Жадана «Депеш Мод», а лише знятий за мотивами літературного твору. Фахівці з кінознавства вважають, що творці хорошої екранізації майстерно відтворюють сутність «і букви, і духу» (А. Базен) першотвору.

Сьогодні молоді люди не обмежені у виборі фільму; зазвичай екранізації доступні для копіювання, скачування, перегляду в Інтернеті, тому потреби створювати фільмотеку кафедри немає. Викладач добирає кінострічку, зважаючи на якість (професійна режисура, акторська майстерність, перевага художнього, естетичного компонентів) та на те, чи немає «небезпеки вульгаризації» (А. Базен), спрощення, викривлення, імітації української літературної класики; на адекватність культурологічного аналізу для дешифрування літературного тексту та кіноекранізації, можливості особистісного розвитку студентів в організованому «діалозі» 3 творцями мистецьких артефактів.

Мета діяльності на заняттях із використанням кінопрезентацій класики - порівняльний аналіз літературного твору та його екранізації задля дослідження особливостей інтерсеміотичного перекодування, для виявлення нових смислів першотексту, формування ціннісних орієнтацій молоді. Справді, «не існує екранізації, яка могла б замінити літературний твір» (Ю. Винничук), а отже, початком роботи над фільмом-екранізацією є прочитання літературного тексту. Науковцями (Л. Бербенець, Л. Брюховецька, О. Брюховецька, О. Лапко, С. Марченко, Л. Нежива та ін.) обгрунтовано, що успішні телефільми на літературній основі стимулюють звернення глядача до книги, до перечитування добре відомих творів, водночас це - позитивна риса гомогенізації культури, наближення класики до масового реципієнта. Однак опитування молоді засвідчує: багато хто зупиняється на перегляді кіноверсії та не читає текст; неякісні екранізації знеохочують до прочитання першотексту або заважають абстрагуватися від отриманої під час перегляду фільму інформації, режисерської презентації книги, невідповідності акторів певним ролям тощо. До речі, за спостереженнями методистів (Н. Гричаник, В. Марко, А. Ситченко та ін.), учителі-практики часто «підмінюють» роботу 3 текстом його переказом, вибірковим читанням окремих епізодів або переглядом кінофільмів.

Плануючи культурологічний аналіз на методологічній основі літературознавчого, передбачаємо осмислення «кінематографічного» в літературі, притаманних мистецтву слова і кіно виражальних засобів, зумовленого кіномисленням письменника, впливом кіно на його світогляд, літературний метод, стиль письма, «протокінематографізм» тексту. Застосовуємо прийоми візуальної інтерпретації твору: робота 3 ілюстраціями, завдання - уявити героя, ситуацію, відкритий фінал; переказати епізоди, які вразили найбільше; «накидати» двома-трьома реченнями візуальний ряд фрагмента; «зобразити» умовність психологічних сцен (уявне, підсвідоме, символи); виокремити «кадри», продумати їх поєднання чи монтаж у «смислове і синтаксичне ціле» (Ю. Лотман); «показати» багатогранність потрактувань літературного тексту в різних видах мистецтва (музика, живопис, кіно, театр тощо), розмаїття читацьких інтерпретацій; прокоментувати відображені автором образи епохи, культурні реалії періоду створення твору.

До «представлення» фільму можуть залучатися студенти, основне завдання - доречно виконати у форматі гіпертексту, наприклад, за зразком вебсторінки «Список екранізованих творів українських письменників» у Вікіпедії (https://uk.wikipedia.org) із «рубриками»: деталі сюжету, акторський склад, творча група, посилання на статті кінокритиків; гіперпосиланнями на інформацію про письменника, художній твір, фрагменти тексту, праці літературознавців, словники, відгуки, мультимедійні аудіо- та відеооб'єкти (фото, постер, трейлер фільму) тощо. Етап емоційного налаштування аудиторії на сприймання фільму передбачає увиразнення зв'язку з метою, завданнями заняття із літературознавчої дисципліни, актуалізацію відповідних знань, зацікавлення аудиторії. Однією з педагогічних умов проведення «кінозаняття» $є$ створення атмосфери психологічного комфорту, невимушеності спілкування, дискусій, спільної творчості.

Підготувати студента філологічного факультету до сприйняття фільму (комунікативний етап заняття) достатньо складно. Для з'ясування теоретико-методологічних кінознавчих знань, набуття навичок естетичної оцінки, аналізу фільму як художньої цілісності з метою «поширення практики інтеграції медіаосвітніх елементів у навчальні програми 3 різних предметів» [3] доречно розробити інтегративні курси за вибором, як-от: «Кінофікація українського літературного дискурсу», «Кіно vs література: контексти екранізацій», «Успішні екранні втілення української класики», «Кінознавство і кінопедагогіка» тощо.

На етапі рефлексії простежуємо кінематографічні засоби екранізації твору, порівнюємо синхронні місця тексту й екрана (сцени, діалоги, описи дії, авторські рядки), інтерпретації одного тексту різними режисерами (наприклад, повість I. Франка «Захар Беркут» екранізовано Й. Роною (1929 р.), Л. Осикою (1971р.), А. Сеїтаблаєвим та Д. Вінном (2019 р.); відзначаємо образно відображені, «схоплені» оператором описи природи, краєвиди; кінематографічні, концептуальні знахідки творчої групи. Форми аналізу кінопрезентацій класики: обговорення рецензій (кінокритиків, письменників, літературознавців), дискусії щодо протилежних відгуків, коментований перегляд фільму, інтерактивний перегляд (з обгрунтуванням своїх варіантів розвитку подій, фіналу); пов’язані з майбутньою професійною діяльністю (моделювання і захист конспекту кіноуроку, уроку з елементами кіноосвіти, медіаосвіти, інтегрованого уроку, засідання кіноклубу, відвідин кінотеатру з наступним обговоренням кіноновинки, планування системи запитань для аналізу культурного контексту фільму тощо). Види діяльності, які розвивають художньо-творчі здібності, вчать «створювати нові елементи медіакультури» [3]: зйомки художнього кіно (фрагментів), написання відгуків, рецензій, коментарів на сайтах для перегляду фільмів, сценарію епізоду, монтаж із малюнків (фотофільм), 
асоціативний (демонстрація ідеї через візуальну метафору); підготовка телекомунікаційних проєктів, вироблення стратегії дистрибуції українського фільму; прийоми: «я в кіно» (вибір ролі, включаючи образи-речі, тварини, яку міг би зіграти студент), «лист одногрупнику» (надіслати кадри, кіноцитати, пояснити свій вибір), «драматизація фільму» (виступ у ролі актора; розповідь, відповіді на запитання від імені кіногероя), «стоп-кадр» (відтворення монологу героя, аналіз епізоду), «сам собі режисер» (опанування в ігровій формі теоретичних понять, як-от «екранізація», «кіномова»; ігрове кіно, «серіальна» адаптація твору, сценічна й кінематографічна версія образу героя тощо). Формуючи індивідуальне критичне судження про фільм, звертаємо увагу студентів на ймовірне використання авторами прийомів маніпулятивного впливу (наприклад, чи має значення для українського глядача те, що фільм В. Бортка «Тарас Бульба» за повістю М. Гоголя, профінансовано Міністерством культури Російської Федерації). Теми для колективних, проблемних обговорень, дискусій: «Чи має українське кіно втілювати спільну державну ідеологію, опиратися на українські традиції, цінності, мову?»; «Як узгодити відповідність кінопрезентації першоджерелу, письменницькому задуму 3 вимогами комерційних, популярних фільмів (ефектні сцени, спецефекти, відомі елітарні актори, «гламурність» зображення тощо)?»; «У наш час література впливає на кіно, чи кіно на літературу?»; «Чи погоджуєтеся Ви із твердженням, що «екранізація цілком справедливо вважається переходом прозового твору на вищий рівень»?» [2]; «Чи доречно рекомендувати для перегляду 3 навчальною метою фільми 3 еротичними сценами?»; «Який вихід із ситуації: культурно не підготовлений читач поповнює ряди культурно не підготовлених глядачів?».
Висновок. Отже, осмислення екранізацій у методичній перспективі пов'язане 3 моделюванням медіаосвітнього навчального процесу у вищій школі, інформатизацією освіти, застосуванням інтегрованого підходу до викладання літератури як реалізації міжпредметних зв'язків (педагогіка, літературознавство, кінознавство), трансформуванням знань у компетентності, зокрема створення мультимедійних аудіо- та відеооб'єктів, формуванням образного, критичного й аудіовізуального мислення.

Перспективи подальших наукових досліджень в означеному напрямі спрямовуватимуться на розроблення та апробацію методики медіаосвіти в закладах загальної середньої і вищої освіти, створення програм iз кіноосвіти для студентів філологічного факультету, а також розвиток рефлексії студентів щодо кінопродукції.

\section{СПИСОК ВИКОРИСТАНОЇ ЛІТЕРАТУРИ}

1. Брюховецька Л. Адаптація чи штурм літературного Евересту? Твори Івана Франка в кіно / Л. Брюховецька // Кіно - Театр. - 2006 - № 6. URL: http://ktm. ukma.edu.ua (дата звернення: 05.11.2019).

2. Кокотюха А. Українським авторам треба вчитися писати для кіно / А. Кокотюха. URL: http://detector. media/infospace/article (дата звернення: 03.10.2019).

3. Концепція впровадження медіаосвіти в Україні. URL: http://detector.media/mediaosvita (дата звернення: 05.11.2019).

4. Нежива Л. Одна сльоза котилася по лиці, як перла по скалі. Стильовий аналіз новели В. Стефаника «Камінний хрест» на тлі порівнянь 3 однойменним кінофільмом Л. Осики / Л. Нежива // Українська література в загальноосвітній школі. - 2012. - № 2. - С. 7-10.

Дата надходження до редакиіï: 11.12.2019 p.

\section{МОЛОДІЖНИЙ СЛЕНГ У СУЧАСНІЙ АНГЛІЙСЬКІЙ ЛЕКСИКОЛОГІї}

У статті проаналізовано проблеми розвитку молодіжного сленгу англійської лексикології. Окреслено деякі підходи до визначення сутності поняття «сленг». Висвітлено види молодіжного сленгу, охарактеризовано низку життєвих ситуацій, в яких сучасна молодь використовує сленгові слова та вирази.

Ключові слова: сленг, сленгові слова і вирази, молодіжний сленг, розмовна мова.

В статье проанализированы проблемы развития молодежного сленга английской лексикологии. Представлены некоторые подходы к определению сущчнсти понятия «сленг». Освешены виды молодежного сленга, охарактеризован ряд жизненных ситуаџий, в которых современная молодежь использует сленговые слова и выражения.

Ключевые слова: сленг, сленговые слова и выражения, молодежный сленг, разговорный язык.

The article analyzes the main problems of the development of youth slang in English lexicology. The basic approaches to the definition of the essence of the term "slang》 are presented. Different types of youth slang are presented and a number of life situations in which young people use slang expressions are characterized. 